\title{
Performance Analysis and Drying Kinetics of Maize in an AflaSTOP Dryer
}

\author{
Ernest Owusu-Sekyere1, George Obeng-Akrofi², Joseph 0. Akowuah ${ }^{3 *}$, Dirk Maier ${ }^{2}$ \\ ${ }^{1}$ College of Engineering, South China Agricultural University, Guangzhou, China \\ ${ }^{2}$ Department of Agricultural and Biosystems Engineering, Iowa State University, Ames, USA \\ ${ }^{3}$ Department of Agricultural and Biosystems Engineering, Kwame Nkrumah University of Science and Technology, Kumasi, \\ Ghana \\ Email: *akowuahjoe@yahoo.co.uk, *joakowuah.soe@knust.edu.gh
}

How to cite this paper: Owusu-Sekyere, E., Obeng-Akrofi, G., Akowuah, J.O. and Maier, D. (2021) Performance Analysis and Drying Kinetics of Maize in an AflaSTOP Dryer. Open Journal of Applied Sciences, 11, 327-342.

https://doi.org/10.4236/ojapps.2021.113024

Received: February 10, 2021

Accepted: March 27, 2021

Published: March 30, 2021

Copyright (c) 2021 by author(s) and Scientific Research Publishing Inc. This work is licensed under the Creative Commons Attribution International License (CC BY 4.0).

http://creativecommons.org/licenses/by/4.0/

\begin{abstract}
The performance of an AflaSTOP dryer which utilises biomass energy for drying maize was investigated. The drying behaviour of maize grains in the dryer was also investigated using ten (10) thin-layer mathematical models. The models were compared based on coefficient of determination $\left(R^{2}\right)$ and Root Mean Square Error $(R M S E)$ values between experimental and predicted moisture ratios. At an average drying air temperature of $50^{\circ} \mathrm{C}$ and drying air velocity of $2.5 \mathrm{~m} / \mathrm{s}$, maize at average moisture content (MC) of $17.5 \%(\mathrm{wb})$ was dried to an average MC of $11.5 \%(\mathrm{wb})$ in three (3) hours. The drying and thermal efficiency were calculated as $81.1 \%$ and $29.6 \%$ respectively. Overall, drying took place in the falling rate period. The Logistics model was best to describe the thin-layer drying kinetics of maize in the dryer with $R^{2}$ value of 0.9902 and $R M S E$ value of 0.04908 .
\end{abstract}

\section{Keywords}

AflaSTOP Dryer, Maize Drying, Thin Layer Drying Kinetics, Drying Efficiency

\section{Introduction}

Maize (Zea mays L.) is an economic staple food in the world especially Sub-Sahara Africa. In Sub-Saharan Africa, it is considered as the most important cereal crop which is cultivated across a large range of ecological zones. According to [1], maize makes a significant contribution towards food security in Sub-Saharan Africa by contributing over $30 \%$ of the daily dietary energy consumption. Drying maize after harvest from high moisture content of $20 \%-30 \%$ to low safe storage moisture content $(<13 \%)$ is necessary to ensure storability of 
maize grains in warm and humid countries like Ghana. However, drying of moist materials is a complicated process involving simultaneous heat and mass transfer [2]. During maize drying, it is recommended that the drying air temperature does not exceed $55^{\circ} \mathrm{C}$ for seed maize (restricted to avoid killing the germ) and $90^{\circ} \mathrm{C}$ for consumption (restricted to avoid cooking the maize kernel and causing fissures of the outer most layer) [3].

In Ghana, smallholder farmers still depend on open-air/sun drying either on the bare ground by the road side or at the market place on tarpaulins. According to [4], this method is associated with various limitations including; dependence on weather conditions, labour intensive, unhygienic, unreliable, time-consuming, non-uniform drying and requiring most often large area for spreading the product out to dry and in some places, have failed to produce expected quality. Losses up to $30 \%$ according to [5] also occur in the daily labor-intensive handling process of spreading crops on the ground, and then gathering and re-bagging them.

Due to the several limitations of the open-air/sun drying method, other efficient and suitable drying methods have been introduced. Most of such dryers utilise electricity, fossil fuels and gas as their source of energy. However, these drying systems usually built for large scale drying have high energy demand and are also very expensive to secure and operate [6]. In addition, farmers are often not prepared to pay for the high drying charges of these drying systems, which are also often centralized and far from farmers, thereby discouraging their patronage.

In Ghana, majority of smallholder maize farmers farm on average land size of 2 hectares with an average production yield of $1.8 \mathrm{MT} / \mathrm{ha}$. With virtually no available alternative drying technologies tailored for the smallholder farmer, access to low cost batch drying systems that can be owned and operated at their level are desirable. The development of the AflaSTOP dryer, a portable batch dryer that can be incorporated into a farmer's normal post-harvest routine is widely considered a viable drying option that allows smallholder farmers to dry their grains to safe storage moisture level at their convenience.

For commercialization and potential scale-up of the AflaSTOP dryer, numerous drying trials are required to rigorously ascertain its technical performance to reflect on its potential for full market diffusion. This can be achieved in addition to field trials using mathematical simulations to optimize the performance. According to [7], to successfully transfer knowledge acquired experimentally from studies on food dehydration into industrial applications, mathematical modelling of drying kinetics is required. Moreover [7] further stated that a mathematical model is an important tool used to optimize operating parameters and to predict performance of a drying system. Numerous mathematical models, empirical and semi-empirical, have been proposed to estimate the drying characteristics of agricultural products [8]. These simple models, also known as thin layer models, allow prediction of mass transfer during dehydration and are applied to simulate drying curves under similar conditions [9] [10]. According to 
[11], many thin-layer drying mathematical models have been developed for predicting drying behaviour of food and agricultural materials. Some of these include; Newton, Henderson and Pabis, Page, Simplified Ficks diffusion equation, Logistics, Two-term exponential models etc. These models are also relevant in the modification and optimization of drying systems for commercialisation as reported by [12] [13]. Studies into thin layer drying kinetics of maize in experimental drying systems are critical to support the potential scale-up of such drying technologies.

Although many studies have been conducted about drying properties for different agricultural products using different drying technologies, no study has been carried out on the drying kinetics of white maize using the AflaSTOP dryer. Additionally, drying indices of maize under drying conditions in the dryer is not available for performance optimization. Therefore, the aim of this study was to analyse the performance and determine a suitable mathematical model for predicting the drying kinetics of maize in a locally fabricated AflaSTOP dryer using thin layer drying models.

\section{Materials and Methods}

\subsection{Description and Mode of Operation of the Dryer}

As presented in Figure 1, the drying system consists of two units; 1) the shallow bed unit and 2) the heat (drying air) supply unit. Parts of the shallow bed unit include: collapsible support frame, center post, collapsible panel, side guard, roof, and tarpaulin base plenum. The heat (drying air) supply unit consists of parts including; furnace, two fans, chimney, attachment pin and a lock, pulley system, duct connector and plate heat exchangers. The dryer is developed to afford smallholder farmers the opportunity to dry their grains irrespective of location and can dry 3 batches per day. The dryer is designed to utilize agro residues such as maize cobs as its main heat source and can dry maize in batches of $500 \mathrm{~kg}$,

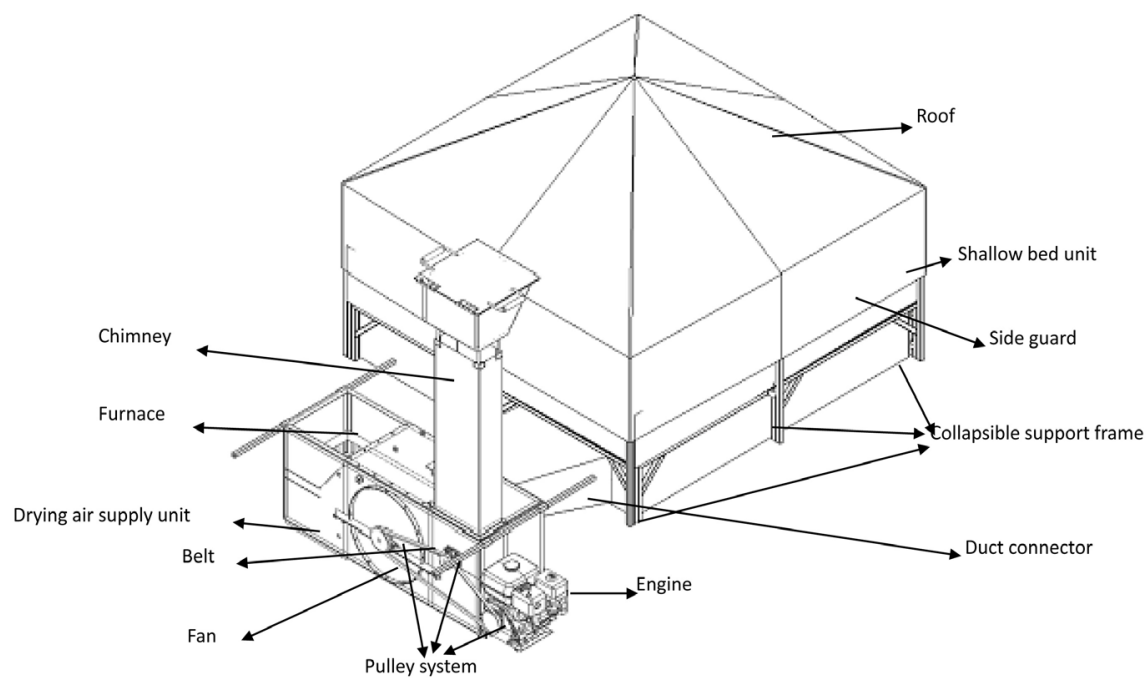

Figure 1. Description of dryer [14]. 
lowering the moisture level from $18 \%-20 \%$ to $12 \%-14 \%$. As shown in Figure 2, the biomass (maize cobs used in this study) is combusted in the combustion chamber (furnace). Heat generated is absorbed by the plate type heat exchangers which in turn heats the high velocity air generated by the intake fan with the aid of the engine connected by a v-belt. The heated air is blown into the plenum of the shallow bed unit through the connecting duct. Heated air in the plenum evaporates the moisture in the grains due to its low relative humidity.

The saturated air rises out into the atmosphere through the open vent in the shallow bed unit. The smoke generated in the combustion chamber is forced out by the exhaust fan through the chimney into the atmosphere. Maize is dried to the required moisture content if the process is continued for few hours with constant supply of heat depending on the initial moisture content of the grains.

\subsection{Maize Variety}

"Obaatanpa", a local white maize variety was obtained from the KNUST Agricultural Research Station farm for the drying experiment. The initial moisture content was determined using ISO 6540-1980 moisture content determination method for maize. $8 \mathrm{~g}$ of ground maize was dried in an oven at $130^{\circ} \mathrm{C}$ for $4 \mathrm{~h}$. Three replications were used for the determination of the initial moisture content and an initial average of $17.5 \% \pm 0.86 \%$ wet basis was recorded.

\subsection{Drying Procedure}

Drying experiments were carried out using the AflaSTOP dryer (Figure 3) locally fabricated at the workshop of the Department of Agricultural and Biosystems Engineering, KNUST, Kumasi.

A total of $250 \mathrm{~kg}$ of "Obaatanpa" white shelled maize at initial MC of $17.5 \%$ $(w b)$ was used for the drying experiment. The dryer powered by a 5-litre capacity diesel generator was allowed to run for at least 20 minutes before the commencement of drying for it to reach steady state condition. Drying air conditions

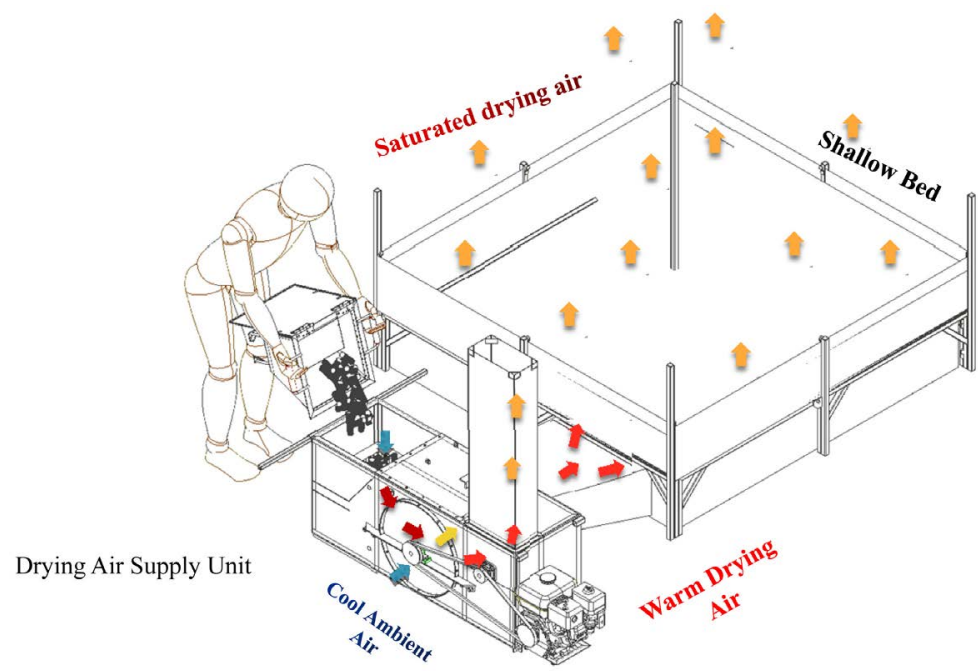

Figure 2. Schematic view of air movement during operation of AflaSTOP dryer [14]. 


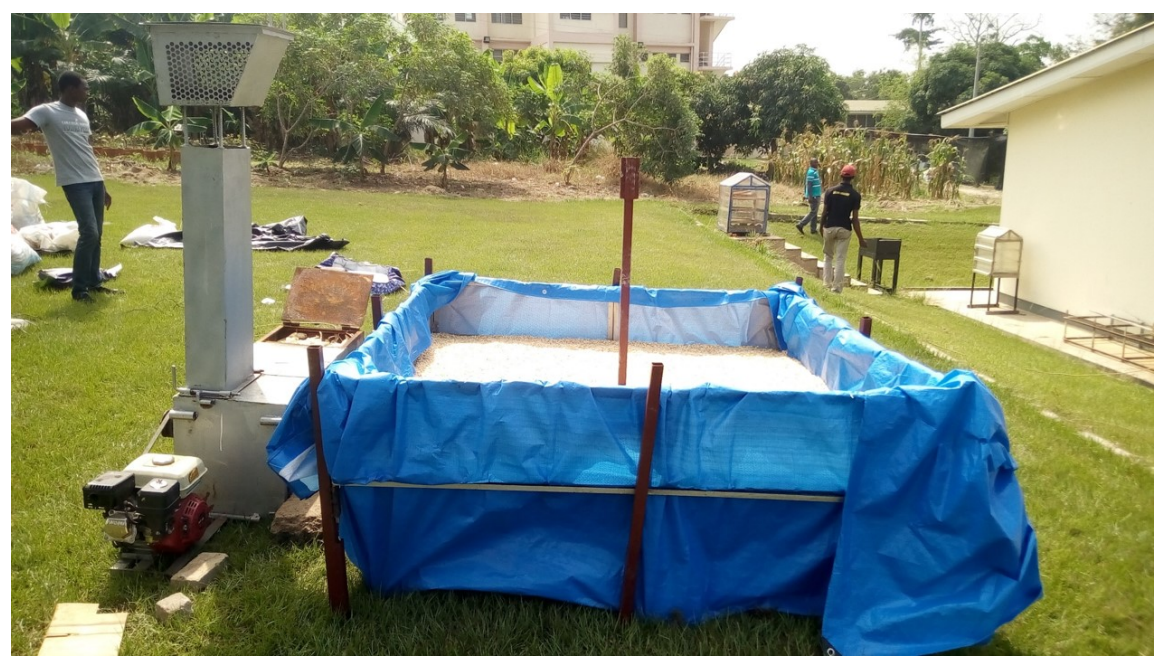

Figure 3. Constructed AflaSTOP dryer at KNUST.

(temperature and relative humidity) were monitored at the plenum of the dryer using Kestrel data loggers positioned at 3 logging positions (Figure 4). Conditions of the ambient were also monitored during the drying process.

The MC of maize grains during the drying experiment was concurrently monitored hourly with a pre-calibrated moisture meter (Dicky-John mini GAC plus moisture analyser with accuracy of $\pm 0.1 \%$ ). Maize grains were sampled at different positions in the dryer and mixed thoroughly before the MC reading was taken and recorded. Three measurements were taken at each period and the means were calculated for analysis.

\subsection{Theories and Calculations}

\section{- Thermal Efficiency}

According to [15], the thermal efficiency of biomass burners with heat exchangers can be determined as stated in Equation (1).

$$
(\%) \eta_{t h}=\frac{Q_{s}}{Q_{a}} \times 100
$$

where,

$$
\begin{aligned}
Q_{s}=M_{a i r} & \times C_{a i r}\left(T_{a i r}-T_{a m b}\right) \\
Q_{a} & =M_{c c} H_{v} \\
M_{a i r} & =V_{a i r} \times D_{a i r}
\end{aligned}
$$

$Q_{a}=$ Heat available for drying $(\mathrm{kJ} / \mathrm{kg}) ;$

$Q_{s}=$ Heat supplied $(\mathrm{kJ} / \mathrm{h})$;

$T_{\text {air }}=$ Average heated air temperature $\left({ }^{\circ} \mathrm{C}\right)$;

$T_{a m b}=$ Average ambient air temperature $\left({ }^{\circ} \mathrm{C}\right)$;

$C_{p_{\text {air }}}=$ Specific heat capacity of $\operatorname{air}\left(\mathrm{kJ} / \mathrm{kg} \cdot{ }^{\circ} \mathrm{C}\right)$;

$M_{\text {air }}=$ Mass flow rate of air $(\mathrm{kg} / \mathrm{h})$;

$M_{c c}$ = Biomass (maize cobs) consumed (kJ/kg;) 


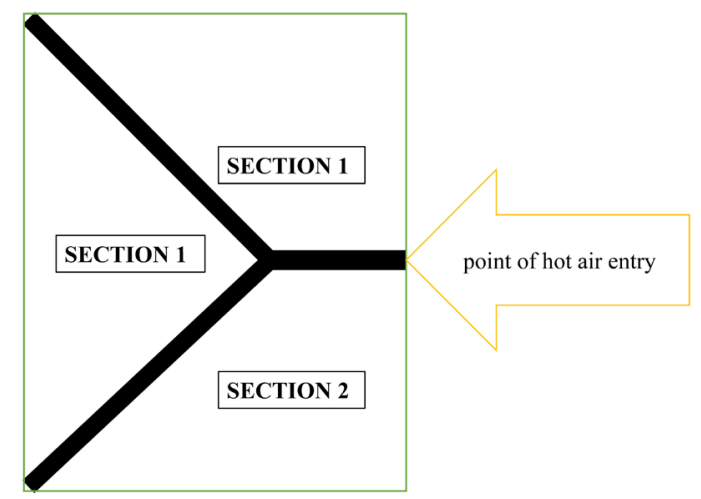

Figure 4. Data logging and sampling positions during the drying experiment.

$H_{v}=$ Gross heating value of maize cob $(\mathrm{kJ} / \mathrm{kg})$;

$V_{\text {air }}=$ volume flow rate of air $\left(\mathrm{m}^{3} / \mathrm{h}\right)$;

$D_{\text {air }}=$ density of air $\left(\mathrm{kg} / \mathrm{m}^{3}\right)$.

\section{- Drying System Efficiency}

The drying system efficiency was determined from the formulae stated below. It is defined as the ratio of the heat used to evaporate moisture from the grains to the energy given to the drying air [16].

$$
\begin{gathered}
\mathfrak{\eta}_{s y s}=\frac{E_{u}}{E_{f}} \\
E_{u}=M_{w} \times L_{v} \\
E_{f}=M_{a} \times C_{p} \times\left(T_{\text {out }}-T_{d}\right)
\end{gathered}
$$

where

$E_{f}=$ Energy given to the drying air;

$E_{u}=$ Energy used to evaporate mass of water;

$M_{a}=$ mass of air $(\mathrm{kg})$;

$C_{p}=$ specific heat capacity of air $\left(\mathrm{kJ} / \mathrm{kg} \cdot{ }^{\circ} \mathrm{C}\right)$;

$l_{v}=$ latent heat of vaporization $(\mathrm{kJ} / \mathrm{kg})$;

$m_{w}=$ mass of water $(\mathrm{kg})$;

$T_{\text {out }}=$ temperature of air going out after drying;

$T_{d}=$ drying air temperature.

- Volume Flow Rate of Air $\left(\mathrm{m}^{3} / \mathrm{h}\right)$

$$
V=\frac{V_{a}}{t}
$$

where $V, V_{a}$ and $t$ are the Volume flow rate, quantity of air $\left(\mathrm{m}^{3}\right)$, and the total drying time respectively.

- Mass Flow rate of Air (kg/s)

$$
m_{\text {air }}=\rho V
$$

where $m_{\text {air }}, \rho$ and $V$ are the mass flow rate of air $(\mathrm{kg} / \mathrm{s})$, density of air $\left(\mathrm{kg} / \mathrm{m}^{3}\right)$ and $V$ volume flow rate of air $\left(\mathrm{m}^{3} / \mathrm{h}\right)$.

\section{- Moisture Content}




$$
M C_{w b}=\frac{M_{m}-M_{d}}{M_{m}}
$$

Moisture loss (\%)

$=$ Initial moisture content $\%\left(M_{i_{w b}}\right)-$ Final moisture content \% $\left(M_{f_{w b}}\right)$

where $M C_{w b}, M_{m}$ and $M_{d}$ are moisture content (wet basis), initial and finial mass of grains.

- Moisture extraction rate $(M E R)$

$$
\begin{gathered}
M E R=\frac{M_{w}}{t} \\
M_{w}=M_{m}-M_{d}
\end{gathered}
$$

where $M E R, M_{w} t, M_{m}$, and $M_{d}$ are the moisture extraction rate, mass of moisture loss, drying time, initial and finial mass of grains.

- Rate of moisture loss $\left(M_{r}\right)$

$$
M_{r}=\frac{\Delta M C}{t}
$$

where, $M_{r}, \triangle M C$ and $t$ represents rate of moisture loss, change in moisture content and time taken for the drying process respectively.

- Volume of fuel consumed $\left(V_{f}\right)$

$$
\begin{aligned}
\left(V_{f}\right)= & \text { Level of fuel in tank after drying period } \\
& \times \text { Length of fuel tank }(22 \mathrm{~cm}) \times \text { breath of fuel tank }(20 \mathrm{~cm})
\end{aligned}
$$

where

level of fuel consumed for drying = Initial level of fuel - finial level of fuel

where $V_{f}=$ volume of fuel used.

\section{- Thin layer mathematical modelling}

Key parameters monitored were MC of maize (maize drying rate), temperature and relative humidity in the dryer and the ambient formed the basis for the thin layer drying kinetics modelling in the dryer using experimental models.

\section{- Determination of moisture ratio $(M R)$}

The moisture ratio during the thin-layer drying of maize in the dryer was calculated using Equation (17).

$$
M R=\frac{M_{t}-M_{e}}{M_{o}-M_{e}}
$$

where $M R$ is the dimensionless moisture ratio, $M_{t}$ is the moisture content $(\% \mathrm{db})$ at time $t$, and $M_{o}$ and $M_{e}$ are the initial and equilibrium moisture contents respectively, on dry weight basis. The values of $M_{e}$ are relatively small compared to $M_{t}$ and $M_{o}$, where error implied in the simplification is negligible [17]. The $M R$ was therefore simplified as shown:

$$
M R=\frac{M_{t}}{M_{o}}
$$

\subsection{Mathematical Models}

The moisture ratio $(M R)$ calculated from the $\mathrm{MC}$ of maize grains during the 
drying experiment were fitted to 10 common thin-layer drying models (Table 1) widely used to describe the drying characteristics of most food products. The mathematical drying models were used to assess and predict the moisture ratio of maize at an average drying air temperature of $50^{\circ} \mathrm{C}$. The best model was selected to describe the drying processes of maize in the dryer. The best fit model to the experimental data was selected using statistical parameters such as the coefficient of determination $\left(R^{2}\right)$ and the root mean square error (RMSE) to assess the goodness of the fit. The best fit model was that which resulted in higher $R^{2}$ and the lowest $R M S E[18]$ [19].

\subsection{Model Fitting}

The fitness of experimental data to the thin-layer drying models was evaluated as reported by [11] where statistical parameters such as the root mean square error $(R M S E)$ and coefficient of determination $\left(R^{2}\right)$ were calculated using Equations 19 and 20 respectively. For better fitting procedures, [29] reported that higher $R^{2}$ and lower $R M S E$ values should be obtained. Regression analysis was done using MATLAB (Version R2015a) statistical computer program.

$$
\begin{gathered}
R M S E=\left[\frac{1}{N} \sum_{i=1}^{N}\left(M R_{\text {exp }, i}-M R_{p r e, i}\right)^{2}\right]^{\frac{1}{2}} \\
R^{2}=1-\frac{\sum_{i=1}^{N}\left[M R_{e x p, i}-M R_{p r e, i}\right]}{\sum_{k=i}^{N}\left[M R_{p r e, i}-\frac{\sum_{k=1}^{n} M R_{p r e, i}}{N}\right]}
\end{gathered}
$$

where:

$M R_{p r e, i}$ is the predicted moisture ratio; $M R_{\text {exp }, i}$ is the experimental moisture ratio; $N$ is the number of observations/readings.

Table 1. Thin layer drying models used for model analysis.

\begin{tabular}{ccc}
\hline Model & Equation & References \\
\hline Henderson and Pabis & $M R=a \mathrm{e}^{-k t}$ & {$[20]$} \\
Wang and Singh & $M R=1+k t+b t^{2}$ & {$[20]$} \\
Newton & $M R=\mathrm{e}^{-k t}$ & {$[21]$} \\
Page & $M R=\mathrm{e}^{-k t^{n}}$ & {$[22]$} \\
Two-term & $M R=\left(a \times \mathrm{e}^{k_{1} t}\right)+(1-a) \times \mathrm{e}^{k_{2} \times a x t}$ & {$[23]$} \\
Weibull & $M R=\exp (-t / a)^{b}$ & {$[24]$} \\
Logarithmic & $M R=\left(a \times \mathrm{e}^{-k t}\right)+c$ & {$[26]$} \\
Midilli, Kucuk and Yapar & $M R=\left(a \times \mathrm{e}^{-k t^{n}}\right)+b t$ & {$[27]$} \\
Approximation of diffusion & $M R=\left(a \times \mathrm{e}^{-k t}\right)+(1-a) \mathrm{e}^{-k b t}$ & {$[28]$} \\
Logistics & $M R=b /\left(1+a \times \mathrm{e}^{k t}\right)$ & \\
\hline
\end{tabular}




\section{Results and Discussion}

\subsection{Variation in Temperature and Relative Humidity with Time}

Figure 5 shows the temperature variation across the furnace and plenum compared to the ambient temperature. The plenum temperature varied between $38^{\circ} \mathrm{C}$ at the start and peaking at $70^{\circ} \mathrm{C}$ when the furnace combustion chamber was restocked with maize cobs. Overall an average plenum temperature of $52.8^{\circ} \mathrm{C}$ was recorded while the average ambient temperature was $33.8^{\circ} \mathrm{C}$. The high temperature trend recorded in the plenum during the drying process was due to the high supply of heat energy from the combustion of maize cobs in the furnace of the AflaSTOP dryer. The recorded temperature in the dryer was high enough to dry the maize grains from the initial MC of $17.5 \%$ to $11.5 \%$ in 3 hours. According to [3], an average temperature of $50^{\circ} \mathrm{C}$ is required for effective seed maize drying. The recorded temperature at the plenum of the dryer is suitable for drying seed maize as well.

Variation in the relative humidity $(\mathrm{RH})$ of the ambient and plenum air is shown in Figure 6. The ambient had an average $\mathrm{RH}$ of $54.8 \%$ compared to the plenum average $\mathrm{RH}$ of $27.7 \%$. The lower the $\mathrm{RH}$ of the air, the higher its ability to absorb moisture. The lower RH at the plenum of the dryer was due to the high temperature which created turbulent effect causing water molecules in the grains to evaporate. This phenomenon caused rapid moisture extraction in the grains as the water molecules were energized by the high drying air temperature to attain high kinetic energy to evaporate the moisture bound in the grains. The water molecules were easily absorbed carried away by the low RH of the surrounding air.

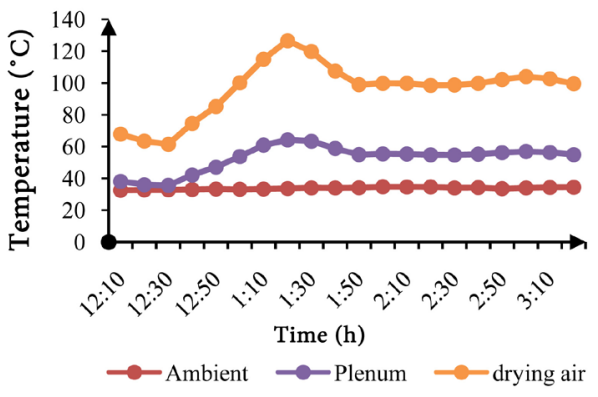

Figure 5. Temperature variation with time during experiment.

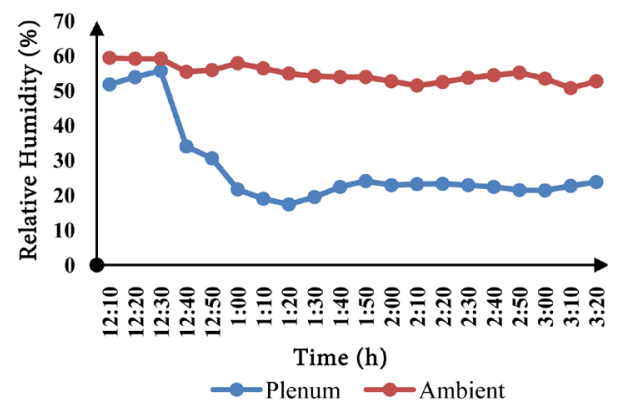

Figure 6. A graph of relative humidity variation with time. 


\subsection{Drying Curves}

The moisture content (MC) of maize grains were monitored at hourly intervals by sampling grains at different positions in the shallow bed unit. The grains were mixed thoroughly before the measurement was done. The change in moisture content of maize with drying time in the AflaSTOP dryer is presented in Figure 7. It was observed that, moisture reduction in maize varied across the drying bed of the dryer with grains closer to the inlet of the heat source drying faster than grains further away from the heat source. However, on average, it was observed that, 3 hours of drying time was used to dry $250 \mathrm{~kg}$ of maize from a moisture content of $17.5 \%$ to an average moisture content of $11.5 \%$. This resulted in a drying rate of about $2 \%$ moisture reduction per hour. In all, about $45 \mathrm{~kg}$ of maize cobs and 0.9 liters of diesel was used to evaporate $28.8 \mathrm{~kg}$ of water. Other performance indicators of the drying experiment is presented in Table 2.

The calculated thermal efficiency $(29.6 \%)$ reveals the percentage of heat used to extract moisture from the grains. The drying system efficiency of $81.9 \%$ was high indicating the dryer is effective in removing moisture $(29 \mathrm{~kg})$ from the maize grains dried within the 3 -hour period. Similar observations were made by [30] [31]. The study by [30] on the performance of a biomass fired dryer for copra drying reported a thermal and drying efficiency of $26 \%$ and $16 \%$ respectively. Work done by [31], on the performance of a biomass dryer for cashew nut drying also reported thermal efficiency and drying efficiency of 35\% and 30.5\% respectively.

Table 2. Experimental overview.

\begin{tabular}{cc}
\hline Parameter & Value \\
Trial Date & $15^{\text {th }}$ March, 2020 \\
Biomass used & Maize cobs \\
Dryer Capacity & $500 \mathrm{~kg}$ \\
Mass of maize & $250 \mathrm{~kg}$ \\
Drying duration & 3 hours \\
Dryer efficiency & $81.1 \%$ \\
Airflow rate of fan & $1079.4 \mathrm{~m} / \mathrm{h}$ \\
Thermal efficiency & $29.6 \%$ \\
Mass of maize cobs & $45 \mathrm{~kg}$ \\
Volume of diesel used & $0.9 \mathrm{litres}$ \\
Diesel utilized to moisture removed ratio & $1: 33$ \\
Initial moisture content $\left(\mathrm{MC}_{\mathrm{wb}}\right)$ & $17.5 \%$ \\
Finial moisture content $\left(\mathrm{MC}_{\mathrm{wb}}\right)$ & $11.5 \%$ \\
Moisture Extraction Rate $\left(\mathrm{MER}^{3}\right)$ & $9.6 \mathrm{~kg} / \mathrm{h}$ \\
Drying rate & $2 \% / \mathrm{h}$ \\
Mass of moisture removed & $28.8 \mathrm{~kg}$ \\
\hline
\end{tabular}




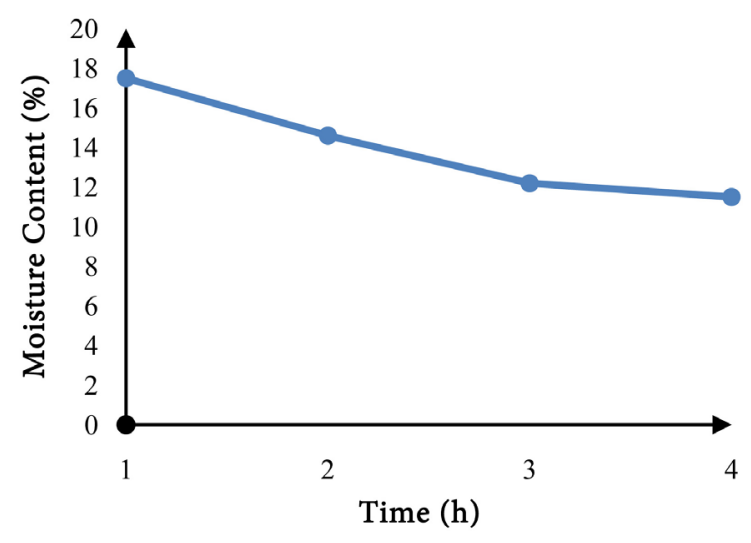

Figure 7. Moisture content of maize versus time.

\subsection{Evaluation of Mathematical Models}

Thin layer drying models presented in Table 1 were fitted to the experimental data. The values of coefficient of determination $\left(R^{2}\right)$ and $R M S E$ for the selected models used to predict the drying behaviour of maize dried in the AflaSTOP dryer are presented in Table 3. The suitable model according to [11], is the model with the highest $R^{2}$ value and the lowest $R M S E$ value. The Logistics model satisfactorily described the drying kinetics of maize dried in the AflaSTOP dryer.

From Table 3, the Logistics model recorded the highest $R^{2}$ value and the least $R M S E$ values of 0.9902 and 0.04908 respectively. This makes it suitable for predicting the drying kinetics of the maize drying process in the AflaSTOP dryer. Drying of the maize grains occurred entirely in the falling rate period which involved moisture removal from the grains by the diffusion process where moisture from inside was transported towards the surface of the grains. During this period, the surface of a maize grain is not covered with a thin layer water, because the internal resistance to moisture transport has become greater than the external resistance. This mechanism of diffusion is best described by Fick's second law of diffusion which assumes that the resistance to water diffusion in a product occurs in the outer layer of the product resulting in the continuous decrease in the drying rate during the course of drying [29]. Other studies have reported the selection of the Logistics model, a semi-theoretical drying model for predicting the drying behavior of some other crops during thin-lay drying experiments. The model has been successfully used to examine the drying kinetics of parsley [32], bamboo sheet [33], and rice [34].

\subsection{Comparison of Experimental and Predicted Models for Moisture Ratios}

The experimental and predicted data values using the Logistics model for moisture ratios of maize dried in the AflaSTOP dryer are shown in Figure 8. It shows the relationship between $M R_{\text {pre }} M R_{\text {exp }}$ and drying time. The overlapping data points show the closeness of the predicted and experimental values. It was observed that the Logistics model provided a very good conformity between the 


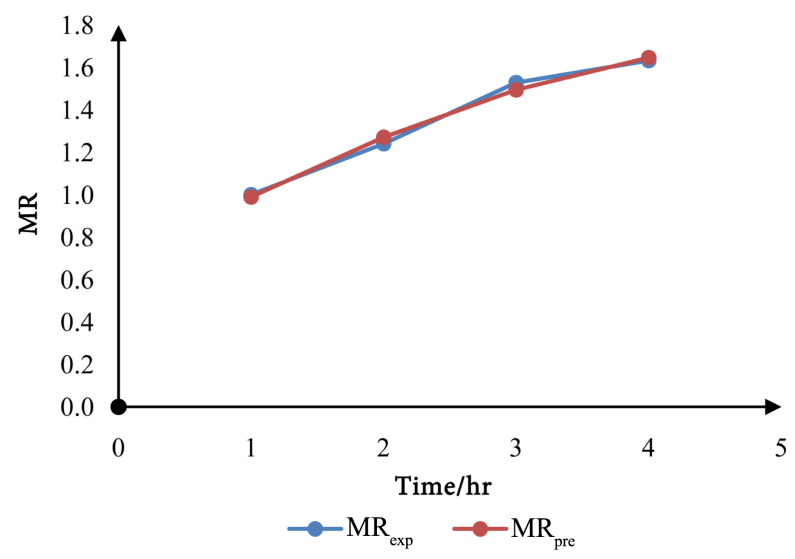

Figure 8. Variation of experimental and predicted Moisture Ratio $(M R)$ with time.

Table 3. Values of $R^{2}$ and RMSE of 10 drying models.

\begin{tabular}{|c|c|c|c|}
\hline Model & Parameters & $R^{2}$ & $R M S E$ \\
\hline Henderson and Pabis & $\begin{array}{c}a=0.896 \\
k=-0.1579\end{array}$ & 0.9459 & 0.08156 \\
\hline Wang and Singh & $\begin{array}{l}a=0.06963 \\
b=0.02503\end{array}$ & 0.9187 & 0.09994 \\
\hline Newton & $k=-0.1242$ & 0.8973 & 0.09171 \\
\hline Page & $\begin{array}{c}k=-0.09162 \\
n=1.247\end{array}$ & 0.9189 & 0.09981 \\
\hline Two-term exponential & $\begin{array}{c}a=-0.6087 \\
k_{1}=-0.1332 \\
k_{2}=0.2097\end{array}$ & 0.8973 & 0.1589 \\
\hline Weibull & $\begin{array}{c}a=13.09 \\
n=-1.626\end{array}$ & 0.8973 & 0.1123 \\
\hline Logarithmic & $\begin{array}{c}a=-1.527 \\
b=2.142 \\
k=0.2821\end{array}$ & 0.9872 & 0.05614 \\
\hline Midilli kucuk & $\begin{array}{c}a=9.989 \\
b=0.06278 \\
k=2.377 \\
n=-0.1372\end{array}$ & 0.9702 & 0.0566 \\
\hline Approximation of diffusion & $\begin{array}{c}a=-4.16 \\
k=0.04527 \\
b=0.0982\end{array}$ & 0.8482 & 0.1932 \\
\hline Logistics & $\begin{array}{c}a=1.664 \\
b=1.855 \\
k=-0.6428\end{array}$ & 0.9902 & 0.04908 \\
\hline
\end{tabular}

experimental and the predicted moisture ratios and best describes the drying kinetics of maize using the AflaSTOP dryer.

Figure 9 presents the comparison of the $M R_{\text {exp }}$ and $M R_{\text {pre }}$ values of maize dried in the dryer. It was observed that, the predicted data banded around the ideal trend line indicating the suitability of the Logistic model in predicting the 


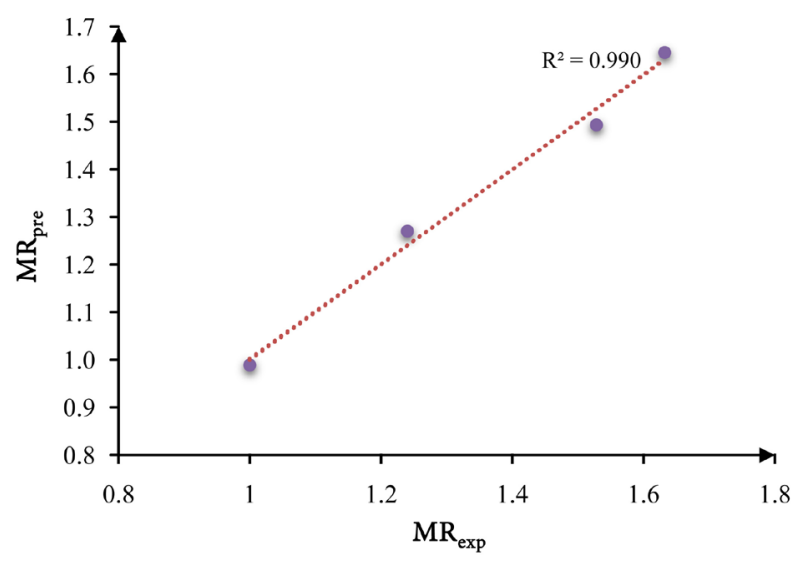

Figure 9. Comparison of $M R_{\text {exp }}$ and $M R_{p r e}$ for maize dried in the AflaSTOP dryer.

drying behaviour of maize in the AflaSTOP dryer. The values obtained from the model were almost the same showing a uniform declination in moisture content from the start of the drying process to the end. The declination in moisture ratio can be attributed to high drying temperature, low relative humidity and high air velocity of the drying air.

\section{Conclusion}

This study analysed the performance of the AflaSTOP dryer and successfully predicted the drying behaviour of maize in the dryer using thin layer models. At an average drying temperature of $50^{\circ} \mathrm{C}$ and air velocity of $2.5 \mathrm{~m} / \mathrm{s}, 250 \mathrm{~kg}$ of white maize at an initial moisture content of $17.5 \%(\mathrm{wb})$ was reduced to $11.5 \%$ at the conditions specified in the dryer for 3 hours. This resulted in a drying rate of $2 \% / \mathrm{h}$ and moisture extraction rate of $9.6 \mathrm{~kg} / \mathrm{h}$. In all about $45 \mathrm{~kg}$ of maize cobs and 0.9 liters of diesel was used to evaporate $28.8 \mathrm{~kg}$ of water. This implies that for every litre of diesel, approximately $32.7 \mathrm{~kg}$ of moisture can be removed from maize using the AflaSTOP dryer. This gives a fuel utilized to moisture removed ratio of 1:33. Among ten (10) thin layer mathematical models analysed, the Logistics model was the best to describe the drying behaviour of maize in the dryer. It had the highest $R^{2}$ value and lowest $R M S E$ value of 0.9902 and 0.04908 respectively. The potential scale-up and adoption of the AflaSTOP dryer by smallholder maize farmers will contribute to reduce postharvest losses in maize at the smallholder level.

\section{Conflicts of Interest}

The authors declare no conflicts of interest regarding the publication of this paper.

\section{References}

[1] International Institute of Tropical Agriculture (IITA) (2014) Maize. https://www.iita.org/cropsnew/maize/

[2] Yilbas, B.S., Hussain, M.M. and Dincer, I. (2003) Heat and Moisture Diffusion in 
Slab Products to Convective Boundary Condition. Heat and Mass Transfer, 39, 471-476. https://doi.org/10.1007/s00231-002-0323-x

[3] Rossouw, M. and Walker, S. (2015) User Experience Evaluation and Qualitative demand Analysis of the Second-Generated (Beta) Prototype of the Potable Shallow Bed Batch Maize Dryer (AflaSTOP).

[4] Tonui, K.S., Mutai, E.B.K., Mutuli, D.A., Mbuge, D.O. and Too, K.V. (2014) Design and Evaluation of Solar Maize Grain Dryer with a Back-up Heater. Research Journal of Applied Sciences, Engineering and Technology, 15, 3036-3043. https://doi.org/10.19026/rjaset.7.639

[5] Opit, G.P., Campbell, J., Authur, F., Armstrong, P., Osekre, E., Washburn, S., Baban, O., McNeill, S., Mbata, G., Ayobami, I. and Reddy, P.V. (2014) A Report on Assessment of Maize Postharvest Losses in the Middle Belt of Ghana.

https://www.k-state.edu/phl/what-we-do/baseline-reports/Ghana\%20-\%20First\%20 PHL\%20Assessment\%20Report\%20-\%20May\%2019-30\%202014-Final\%20Report\% 209-3-14.pdf

[6] Kaaya, A.N. and Kyamukangire, W. (2010) Drying Maize Using Biomass-Heated Natural Convection Dryer Improves Grain Quality during Storage. Journal of Applied Science, 10, 967-974. https://doi.org/10.3923/jas.2010.967.974

[7] Babalis, S.J. and Belessiotis, V.G. (2004) Influence of the Drying Conditions on the Drying Constants and Moisture Diffusivity during the Thin-Layer Drying of Figs. Journal of Food Engineering, 65, 449-458. https://doi.org/10.1016/j.jfoodeng.2004.02.005

[8] Mirzaee, E., Rafiee, S. and Keyhani, A. (2010) Evaluation and Selection of Thin-Layer Models for Drying Kinetics of Apricot (cv. NASIRY). Agricultural Engineering International: CIGR Journal, 12, 111-116.

[9] Doymaz, I. (2007) Air-Drying Characteristics of Tomatoes. Journal of Food Engineering, 78, 1291-1297. https://doi.org/10.1016/j.jfoodeng.2005.12.047

[10] Purkayastha, M.D., Nath, A., Deka, B.C. and Mahanta, C.L. (2013) Erratum to: Thin Layer Drying of Tomato Slices. Journal of Food Science and Technology, 50, 654. https://doi.org/10.1007/s13197-011-0532-8

[11] Chayjan, R.A., Peyman, M.H., Esna-Ashari, M. and Salari, K. (2011) Influence of Drying Conditions on Diffusivity, Energy and Color of Seedless Grape after Dipping Process. Australian Journal of Crop Science, 5, 96-103.

[12] Corrêa, P.C., Botelho, F.M., Oliveira, G.H.H., Goneli, A.L.D., Resende, O. and de Carvalho Campos, S. (2011) Mathematical Modeling of the Drying Process of Corn Ears. Acta Scientiarum Agronomy, 33, 575-581. https://doi.org/10.4025/actasciagron.v33i4.7079

[13] Gely, M.C. and Giner, S.A. (2007) Diffusion Coefficient Relationships during Drying of Soya Bean Cultivars. Biosystems Engineering, 96, 213-222.

https://doi.org/10.1016/j.biosystemseng.2006.10.015

[14] United StatesAgency for International Development (USAID) (2016) Assembly, Operation and Maintenance of an Easy Dry M500.

https://www.acdivoca.org/2016/02/easydry-m500-assembly-operation-and-mainten ance-manual/

[15] Bitog, J.P.P., Elauria, J.C., Elepaño, A.R. and Resurreccion, A.N. (2009) Design, Fabrication and Evaluation of a Direct-Fired Corncob Furnace for Corn Drying. Philippines Journal of Agricultural and Biosystems Engineering, 7, 3-15.

[16] Balbine, M., Marcel, E., Kuitche, A. and Zeghamtic, B. (2015) Experimental Evaluation of the Thermal Performance of Dryer Airflow Configuration. International 
Journal of Energy Engineering, 5, 80-86.

[17] Hussein, J.B., Filli, K.B. and Oke, M.O. (2016) Thin Layer Modeling of Hybrid, Solar and Open Sun Drying of Tomato Slices. Research Journal of Food Science and Nutrition, 1, 15-27. https://doi.org/10.31248/RJFSN2016.010

[18] Duc, L.A., Han, J.W. and Keum. D.H. (2011) Thin Layer Drying Characteristics of Rapeseed (Brassica napus L.). Journal of Stored Products Research, 47, 32-38. https://doi.org/10.1016/j.jspr.2010.05.006

[19] Radhika, G.B., Satyanarayana, S.V. and Rao, D.G. (2011) Mathematical Model on Thin Layer Drying of Finger Millet (Eluesine coracana). Advance Journal of Food Science and Technology, 3, 127-131.

[20] Kaleta, A. and Górnicki, K. (2010) Some Remarks on Evaluation of Drying Models of Red Beet Particles. Energy Conversion and Management, 51, 2967-2978. https://doi.org/10.1016/j.enconman.2010.06.040

[21] Aktas, M., Ceylan, I. and Yilmaz, S. (2009) Determination of Drying Characteristics of Apples in a Heat Pump and Solar Dryer. Desalination, 239, 266-275.

https://doi.org/10.1016/j.desal.2008.03.023

[22] Arumuganathan, T., Manikantan, M.R., Rai, R.D., Anandakumar, S. and Khare, V. (2009) Mathematical Modeling of Drying Kinetics of Milky Mushroom in a Fluidized Bed Dryer. International Agrophysics, 23, 1-7.

[23] Arabhosseini, A., Huisman, W., Van Boxtel, A. and Muller, J. (2009) Modeling of Thin Layer Drying of Tarragon (Artemisia dracunculus L.). Industrial Crops Products, 29, 53-59. https://doi.org/10.1016/j.indcrop.2008.04.005

[24] Aghbashlo, M., Kianmehr, M.H., Khani, S. and Ghasemi, M. (2009) Mathematical Modelling of Thin-Layer Drying of Carrot. International Agrophysics, 23, 313-317.

[25] TürkToğrul, İ. and Pehlivan, D. (2002) Mathematical Modelling of Solar Drying of Apricots in Thin Layers. Journal of Food Engineering, 55, 209-216. https://doi.org/10.1016/S0260-8774(02)00065-1

[26] Midilli, A., Kucuk, H. and Yapara, Z. (2002) New Model for Single-Layer Drying. Drying Technology, 20, 1503-1513. https://doi.org/10.1081/DRT-120005864

[27] Nema, P.K., Mohapatra, D., Daniel, A. and Mishra, S. (2013) Modeling Pulse Microwave Drying Kinetics of Ginger (Zingiber Officinale R.). Journal of Food Research and Technology, 1, 46-58.

[28] Sledz, M., Wiktor, A., Rybak, K., Nowacka, M. and Witrowa-Rajchert, D. (2016) The Impact of Ultrasound and Steam Blanching Pre-treatments on The Drying Kinetics, Energy Consumption and Selected Properties of Parsley Leaves. Applied Acoustics, 103, 148-156. https://doi.org/10.1016/j.apacoust.2015.05.006

[29] Ertekin, C. and Ziya Firat, M. (2017) A Comprehensive Review of Thin-Layer Drying Models Used in Agricultural Products. Critical Reviews in Food Science and Nutrition, 57, 701-717. https://doi.org/10.1080/10408398.2014.910493

[30] Sachidananda, S., Din, M., Chandrika, R., Shahoo, G.P. and Dam Roy, S. (2014) Performance Evaluation of a Biomass Fired Dryer for Copra Drying: A Comparison with Traditional Drying in Subtropical Climate. Journal of Food Process Technology, 5, Article No. 294.

[31] Saravanan, D., Wilson, V. and Sudhakar, K. (2015) Design and Performance Evaluation of Biomass Dryer for Cashew Nut Processing. Advances in Applied Science Research, 6, 101-111. http://www.pelagiaresearchlibrary.com

[32] Soysal, Y., Öztekin, S. and Eren, Ö. (2006) Microwave Drying of Parsley: Modelling, Kinetics, and Energy Aspects. Biosystems Engineering, 93, 403-413. 
https://doi.org/10.1016/j.biosystemseng.2006.01.017

[33] Bal, L.M., Kar, A., Satya, S. and Naik, S.N. (2010) Drying Kinetics and Effective Moisture Diffusivity of Bamboo Shoot Slices Undergoing Microwave Drying. International Journal of Food Science \& Technology, 45, 2321-2328. https://doi.org/10.1111/j.1365-2621.2010.02402.x

[34] Cihan, A., Kahveci, K. and Hacıhafizoğlu, O. (2007) Modelling of Intermittent Drying of Thin Layer Rough Rice. Journal of Food Engineering, 79, 293-298.

https://doi.org/10.1016/j.jfoodeng.2006.01.057 